18. van Roon-Djordjevic, B., and Cerfontain-van Staalen, I.: Urinary excretion of histidine metabolites as an indication for folic acid and vitamin $B_{12}$ deficiency. Clin. Chim. Acta, 41: 55 (1972).

19. 2,4,4- $\left[{ }^{2} \mathrm{H}_{3}\right]$-DL-Glutamic acid is available from Sharp \& Dohme, GmbH, D-8 München 80 , Leuchtenbergring 20, Germany.

20. We are indebted to Drs. E. Scarpetta and R. J. Steinmann for their kind collaboration.

21. This work was supported by the Schweizerische Nationalfonds zur Förderung der wissenschaftlichen Forschung, Projects nos. 3.3170.74 and 3.3050.74.

22. The present address of PD Dr. K. Baerlocher is: Ostschweizerisches Kinderspital, St. Gallen, Switzerland.

23. Requests for reprints should be addressed to: PD Dr. A. Niederwieser, Med.-Chem. Abteilung, Universitäts-Kinderklinik, CH-8032 Zürich, Steinwiesstr. 75, Switzerland.

24. Accepted for publication November 17, 1975
Chimeric calf enzyme replacement therapy lysosomes $\alpha$-mannosidase mannosidosis

\title{
Enzyme Replacement Therapy-An Experiment of Nature in a Chimeric Mannosidosis Calf
}

\author{
R. D. JOLLY, ${ }^{(26)}$ K. G. THOMPSON, C. E. MURPHY, B. W. MANKTELOW, A. N. BRUERE, AND B. G. \\ WINCHESTER \\ Faculty of Veterinary Science, Massey University, Palmerston North, New Zealand and Department of \\ Biochemistry, Queen Elizabeth College, University of London, England (BGW)
}

\section{Extract}

This paper describes an experiment of nature involving a chimeric calf with mannosidosis which had obtained a natural transplant of lymphocytes from its normal twin during fetal development as a result of fusion of the placentas. Karyotyping of 200 peripheral blood lymphocytes showed that $77 \%$ were $60, \mathbf{x x}$ and $23 \% 60, x y$. The $\alpha$-mannosidase $\mathrm{pH}$ dependence activity profiles obtained for the chimera were similar to those for a mannosidosis calf in brain, liver, kidney, and plasma but for peripheral lymphocytes and lymph node extracts enzyme activities approaching those of the normal control calf were measured at $\mathrm{pH}$ 4.0-4.3. In the chimera, vacuolation of macrophages and fixed reticuloendothelial cells in lymph nodes and of pancreatic exocrine cells was considerably less than was observed in any of the 35 other calves with mannosidosis. There were considerably fewer oligosaccharides in the brain, lymph node, and liver of the chimera calf than in any of the five mannosidosis control calves. There is little doubt that the $\alpha$-mannosidase produced by the population of normal cells influenced the pathology of the disease, but failure to significantly prevent the eventual clinical course even under these favorable transplant conditions is indicative that tissue or organ transplants are unlikely to be a successful cure for diseases with severe neurologic manifestations. If this disease had been purely visceral then it is postulated that the transplant would have been reasonably effective.

\section{Speculation}

Although acidic $\alpha$-mannosidase supplied by a natural transplant of lymphocytes, and perhaps other cells, was unable to cure or prevent all clinical manifestations of mannosidosis, the therapeutic effect noted in visceral organs indicates that transplants may be an effective means of treating some inborn errors of lysosomal catabolism that occur without severe neurologic involvement. The reduction of storage material within the brain of the chimera suggests that larger amounts of exogenous enzyme supplied over a prolonged period might be more effective in storage diseases with neurologic manifestations. If it can be established that a concentration gradient for storage material exists between certain tissues and tissue fluids then it may not be essential to actively deliver enzyme to the central nervous system.

Recent advances in prenatal diagnosis of inborn lysosomal disorders and the detection of heterozygous individuals have improved the opportunity for control of these inherited diseases. Despite this progress, children will continue to be born with diseases of this type and will need whatever treatment is available. Specific therapy must include an alternative means of degrading the storage material, either by enzyme replacement or by activating the product of the defective gene. The replacement of an enzyme may be attempted either by parenteral infusion of a purified enzyme preparation or by an organ or tissue graft which would then provide a continuous endogenous supply of the required enzyme. With a few exceptions empirical attempts at therapy have not been encouraging and if specific therapy is to be successful, then it is likely to follow the gradual accumulation and analysis of data from specific experiments. This paper describes an experiment of nature involving a chimeric calf with mannosidosis which had obtained a natural transplant of lymphocytes from its normal twin during fetal development as a result of fusion of the placentas.

Mannosidosis is a relatively common inherited lysosomal storage disease of Angus cattle associated with the deficiency of acidic $\alpha$-mannosidase ( $\mathrm{pH} 4.3$ ) and the consequent storage of oligosaccharides containing mannose and $\mathrm{N}$-acetylglucosamine. $(8,10,19)$. The calf in question was recognized during a mass screening program aimed at controlling the disease by identifying heterozygous animals in Angus bull breeding herds in New Zealand (11-13), and was further investigated as part of a continuing program using bovine mannosidosis as a model lysosomal storage disease. 


\section{MATERIALS AND METHODS}

\section{EXPERIMENTAL ANIMALS}

The proband calf was a castrated male first seen at 9 months of age when a clinical diagnosis of mannosidosis was made. Its sire was an obligate heterozygote and the dam of the calf had been previously designated as heterozygous on the basis of her plasma $\alpha$-mannosidase activity. Plasma $\alpha$-mannosidase activity in the calf was negligible but the activity of this enzyme in lymphocytes was within the lower part of the normal range. As this animal was a twin, it was postulated that the anomalous result could be explained on the basis of chimeric blood. Tissues for further biochemical and histopathologic examinations were collected after euthenasia at approximately 14 months of age when the disease was clinically advanced.

Control tissues for enzyme assays and oligosaccharide estimations were obtained from two normal Angus and Hereford calves of approximately 12 months of age, and from five Angus calves with mannosidosis aged up to 12 months. Tissues from the above animals plus 30 other mannosidosis calves up to 18 months of age were used as controls for histopathologic studies.

\section{CHROMOSOME PREPARATIONS}

Chromosome preparations for karyotype studies were prepared by a modification of the whole-blood technique described by Basrur and Gilman (2). Colchicine was added to the cultures at 48 $\mathrm{hr}$ to arrest the dividing cells in metaphase. The cells were fixed in acetic acid-ethanol solution (3:1) and stained with Giemsa. The chromosomes from 200 good mitotic spreads from two different cultures were counted and the sex chromosome content of each was recorded.

\section{TREATMENT OF TISSUES}

Lymphocytes were separated from whole blood by a modification of the method of Boyum (3). Blood was collected by venipuncture into 2.0 by $10-\mathrm{ml}$ Vacutainers containing EDTA as anticoagulant. After centrifugwtion at $1,800 \times g$ for $10 \mathrm{~min}$ the buffy coats from each tube were pooled and diluted with $2.0 \mathrm{ml}$ $0.85 \% \mathrm{NaCl}$. This cell suspension was then layered gently on 3.0 ml sodium metrizoate/Ficoll mixture (SG 1.077) (22) and centrifuged at $400 \times g$ for $30 \mathrm{~min}$. The lymphocytes, deposited at the interface, were removed and washed twice in $0.85 \% \mathrm{NaCl}$ to remove contaminating platelets and once in $0.15 \mathrm{M} \mathrm{NH}{ }_{4} \mathrm{Cl}$ to lyse contaminating erythrocytes. These cells were stored as a pellet at $-12^{\circ}$ until required for enzyme assay, when they were homogenized by sonication in $1.5 \mathrm{ml} 0.85 \% \mathrm{NaCl}$ containing $0.1 \%$ Triton $X-100$ (23). After centrifugation at $1,800 \times g$ for $10 \mathrm{~min}$ the supernatant was retained for assay. Plasma samples were collected from heparinized blood and stored at $-12^{\circ}$ until assayed.

Tissues collected at autopsy for assay were also stored at $-12^{\circ}$ until required. For enzyme assays, tissues homogenates were prepared in distilled water $(10 \% \mathrm{w} / \mathrm{v})$, whereas those for storage product estimations were prepared in $10 \%$ trichloracetic acid $(10 \%$ $\mathrm{w} / \mathrm{v}$ ), using a Potter-Elvehjem-type homogenizer. Homogenates were centrifuged at $20,000 \times g$ for $15 \mathrm{~min}$ with the supernatants being retained. Extracts destined for storage product estimations were further treated by extracting six times with equal volumes of ether to remove trichloroacetic acid and then neutralized with dilute ammonia. All extracts, with the exception of those from lymph nodes, were lyophilized and reconstituted in a smaller volume of glass-distilled deionized water. To purify the extract further, $1.0 \mathrm{ml}$ of each of the samples was loaded on to a Sephadex G-25 column $(25$ by $1.3 \mathrm{~cm}$ ) and eluted with distilled deionized water. Storage type oligosaccharides, as measured and characterized by Hocking et al. (8), were eluted in a characteristic pattern for each of the three mannosidosis tissues. The appropriate fractions were pooled for quantitative assays. Similar fractions were collected from the chimeric and control tissues.

\section{ENZYME ASSAYS}

$\alpha$-Mannosidase activities were assayed in a range of citric acid-sodium phosphate buffers from $\mathrm{pH} 3.5$ to $\mathrm{pH} 8.0$ and using the fluorigenic substrate, 4-methylumbelliferyl- $\alpha, D$-mannopyranoside. The reaction mixtures consisted of $0.2 \mathrm{ml}$ buffer, 0.1 $\mathrm{ml}$ tissue homogenate, and $0.1 \mathrm{ml} 10 \mathrm{mM}$ substrate solution. After incubation for $30 \mathrm{~min}$ at $37^{\circ}$, the reaction was stopped by the addition of $2.0 \mathrm{ml} 0.5 \mathrm{M}$ glycine buffer $(\mathrm{pH} \mathrm{10.4).} \mathrm{Fluorescence}$ was measured on a Turner model 111 fluorometer.

\section{STORAGE PRODUCT ESTIMATION}

Storage-type oligosaccharides were estimated on the basis of neutral carbohydrate, determined by a phenol- $\mathrm{H}_{2} \mathrm{SO}_{4}$ method (7), and of hexosamine, determined by a modification of the method of Blix as described by Hocking et al. (8).

\section{PREPARATION OF TISSUES FOR HISTOPATHOLOGY}

Routine paraffin sections stained with haematoxylin and eosin were prepared from tissues fixed in either $10 \%$ formol saline or Bouin's solution. Resin-embedded sections were prepared from finely sliced tissue segments fixed in a mixture of $3 \%$ glutaraldehyde and $2 \%$ formaldehyde in $0.1 \mathrm{M}$ phosphate buffer $(\mathrm{pH} 7.2)$ for $3 \mathrm{hr}$ and postfixed in $1 \%$ osium tetroxide in $0.1 \mathrm{M}$ phosphate buffer (pH 7.2) for a further $3 \mathrm{hr}$. These tissues were embedded in epoxy resin (24) after dehydration in graded alcohol solutions. Sections of $0.5-1.0 \mu \mathrm{m}$ thickness were cut with glass knives and stained with $1 \%$ toluidine blue for $30 \mathrm{sec}$ on a hotplate at $80^{\circ}$ and counterstained with $4 \%$ basic fuchsin for $20 \mathrm{sec}$.

\section{RESULTS}

\section{IDENTIFICATION OF CALF AS BLOOD CHIMERA}

Karyotyping of 200 peripheral blood lymphocytes showed that $77 \%$ were $60, \mathrm{xx}$ and $23 \% 60, \mathrm{xy}$. This finding is indicative that the calf was a blood chimera and that it had recieved lymphocytes from its female co-twin through placental fusion.

\section{TISSUE $\alpha$-MANNOSIDASE ACTIVITIES}

Results of $\alpha$-mannosidase assays on a variety of tissues from the chimera, a mannosidosis calf, and a normal control calf are shown in Figure 1. The $\mathrm{pH}$ dependence activity profiles of tissues from the normal and mannosidosis calves were similar to those found in previous studies $(8,19)$. The profiles obtained for the chimera were similar to those for the mannosidosis calf in brain, liver, kidney, and plasma, but for peripheral lymphocytes and lymph node extracts, enzyme activities approaching those of the normal control calf were measured at $\mathrm{pH} 4.0-4.3$. In all calves there was a $\alpha$-mannosidase activity measured at higher $\mathrm{pH}$ values and reflecting activity of isoenzymes believed to be of nonlysosomal origin and with $\mathrm{pH}$ optima of 5.5 and 6.6. These enzymes are not deficient in mannosidosis.

\section{PATHOLOGY}

Histologic studies showed that the mannosidosis control calves had lesions typical of mannosidosis $(9,21)$ and confirmed that the normal-appearing calves were normal. The degree of vacuolation of neurones in the chimera was essentially the same as in the 35 mannosidosis controls (Fig. 2, $a$ and $b$ ) but there was considerably less vacuolation in the chimera's pancreas (Fig. $2 c$ and $d$ ) and lymph nodes (Fig. 2, $e$ and $f$ ). Vacuolation occurred in reticuoloendothelial cells of the spleen and liver of the chimera and mannosidosis controls, but a subjective assessment suggested that this was less severe in the chimera's Kuppfer cells.

\section{STORAGE OF OLIGOSACCHARIDES}

The relative amounts of extracted oligosaccharides in the liver, brain, and lymph nodes of the chimera, five mannosidosis, and two 

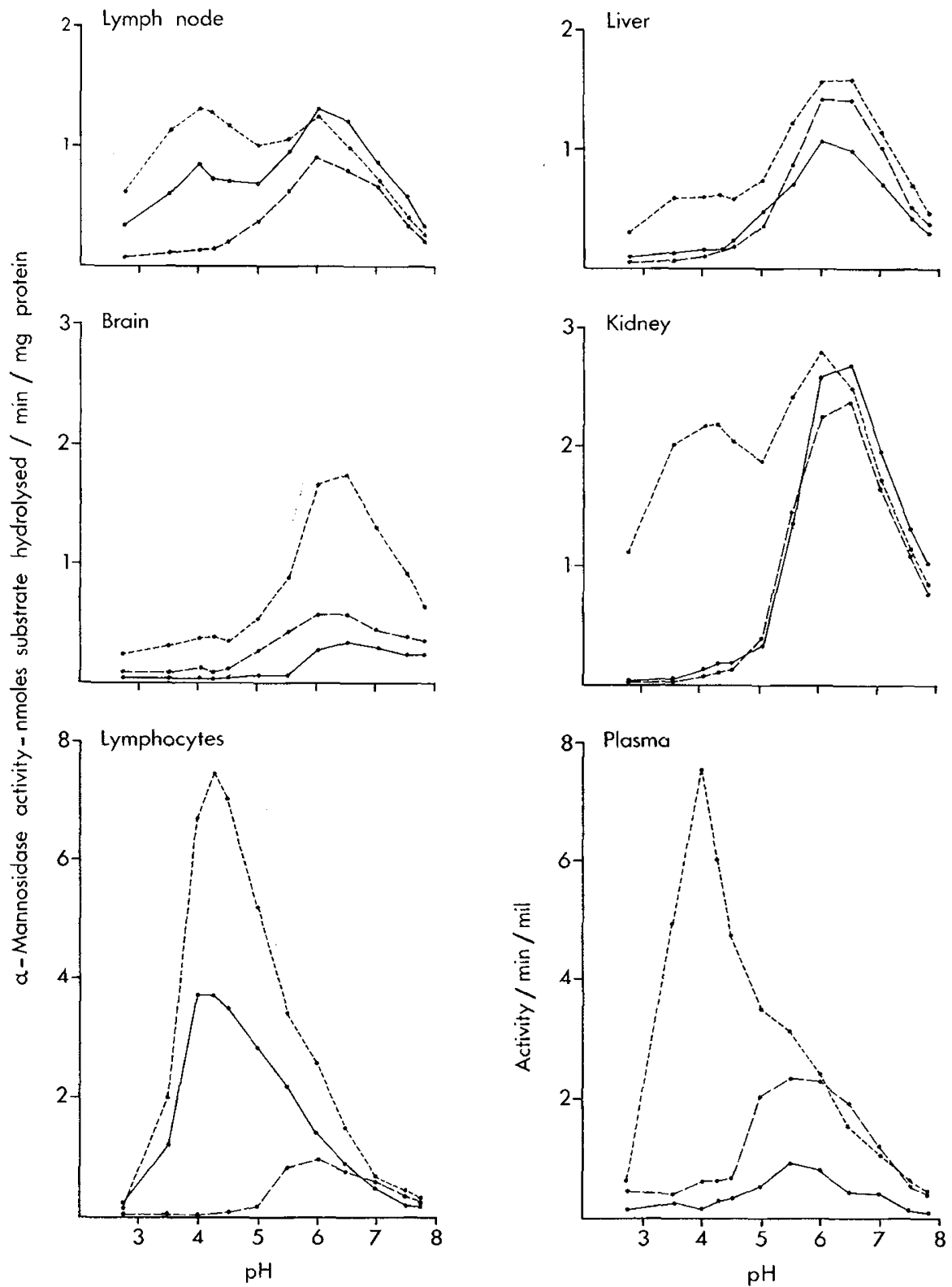

Fig. 1. $\alpha$-Mannosidase $\mathrm{pH}$ dependence activity profiles for plasma, lymphocytes, and various tissues from a normal calf $(\boldsymbol{\bullet}-\ldots)$, a mannosidosis of $(-\ldots)$, and the chimeric calf

normal control calves are presented in terms of neutral carbohydrate and hexosamine in Table 1 . There was considerably less oligosaccharide in the brain, lymph node, and liver of the chimera calf than in any of the five mannosidosis control calves. Although the chimera had more oligosaccharide than the two normal controls, it more closely resembled them in this respect than the calves with mannosidosis. In the liver a large and variable amount of neutral carbohydrate, even in the normal controls, overshadowed any difference expected because of presence of storage product. A difference, however, was clearly shown when oligosaccharides were expressed as hexosamine.

\section{DISCUSSION}

The fortuitous recognition that a calf with mannosidosis was also a blood chimera provided a model for studying some aspects of enzyme replacement therapy. Blood chimeras are not uncommon in cattle. Although natural twinning rates are low in this species, fusion of the placentas and chorionic blood vessels occurs in a high proportion of twin pregnancies, allowing transfer of blood cells which may become implanted in the co-twin and produce their own cell lines. Such blood chimeras may be easily recognized by blood typing or in chromosome preparations if the twins are of opposite sex. In the present case of mannosidosis the calf was not only endowed with a population of lymphocytes from a co-twin of the opposite sex, but it was concluded on the basis of $\alpha$-mannosidase assays of peripheral lymphocytes and lymph node and a knowledge of levels of this enzyme in lymphocytes of normal and heterozygous individuals (20) that the co-twin was normal. Unfortunately, the twin was not available for study, although this does not significantly detract from the conclusions drawn.

In the chimeric mannosidosis calf there is little doubt that $\alpha$-mannosidase produced by the population of normal cells influenced the pathology of the disease. The vacuolation of macrophages and fixed reticuoloendothelial cells of lymph nodes was very much less that was seen in the 35 mannosidosis cases used as controls. It is possible that these cells may have originated from the normal co-twin, but it is considered more likely that they obtained some enzyme by absorption of enzyme provided by the normal lymphocytes that must have colonized the lymph nodes of this calf. This colonization must have been significant, as $\alpha$-mannosidase activity in lymph nodes either approached or was within 

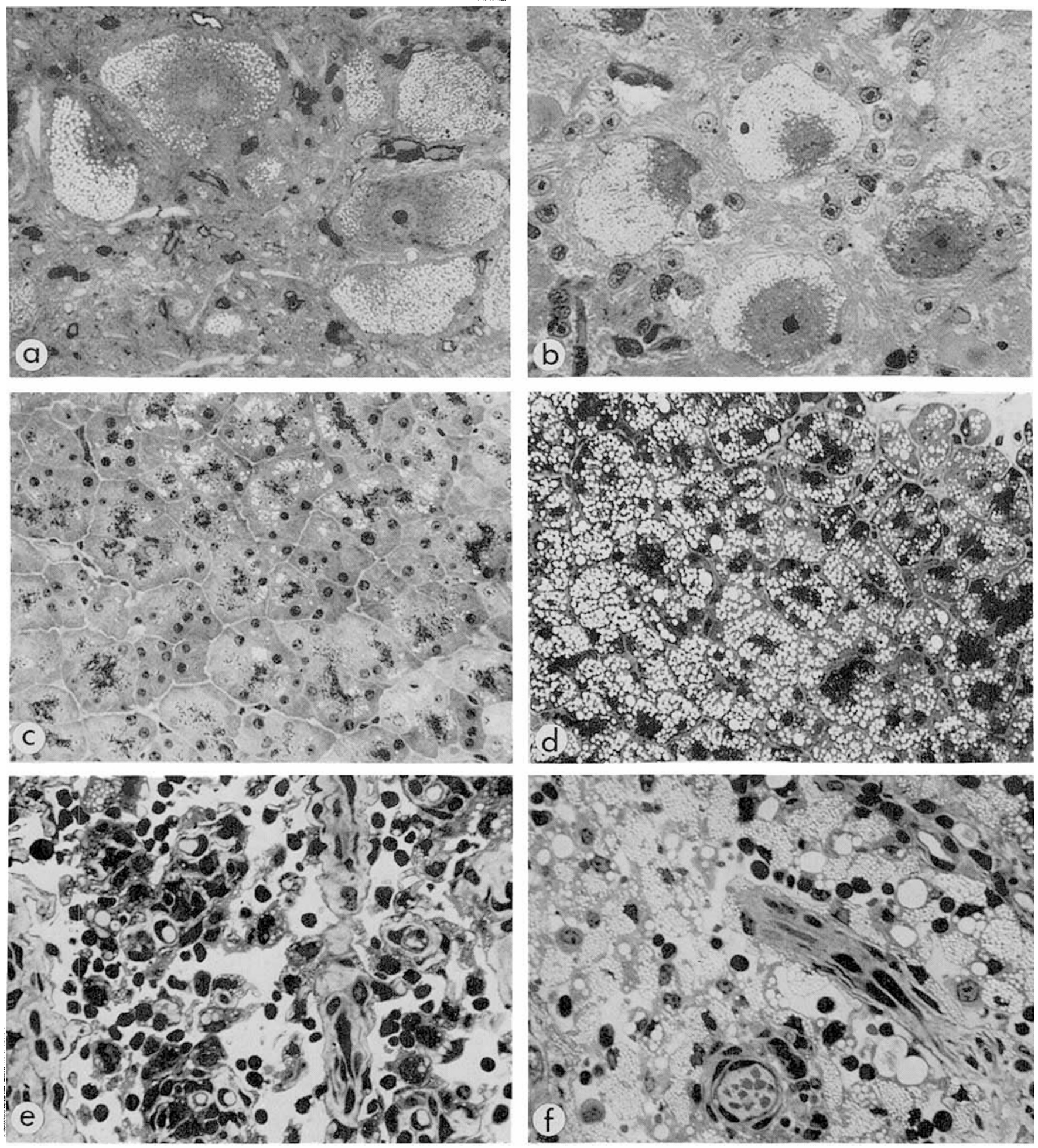

Fig. 2. $a$ : vacuolated neurones from the chimeric calf, (plastic embedded: toluidine blue, $\times 300$ ); $b$; vacuolated neurone from a mannosidosis calf (plastic embedded; toluidine blue, $\times 400$ ); $c$ : pancreas from the chimeric calf (plastic embedded; toluidine blue, $\times 300$ ); $d$ : pancreas from a calf with mannosidosis (plastic embedded; toluidine blue, $\times 300$ ); $e$ : medulla of lymph node from the chimeric calf (plastic embedded; toluidine blue, $\times 450$ ); $f:$ medulla of lymph node from a mannosidosis calf (plastic embedded; toluidine blue, $\times 450$ ).

the normal range. (Fig. 1). The vacuolation of the pancreas was also considerably reduced in the chimera. The reason for this is not clear, but it is possible that small amounts of enzyme were released into the blood stream and tissue fluids and were taken up in sufficient quantity to reduce the storage of oligosaccharides and consequent vacuolation. It has been shown in tissue cultures of fibroblasts that deficient enzyme can be taken up by cells from the culture medium $(6,15)$, and that even quite minor amounts can correct an inherited defect $(1,17)$. The population of normal lymphocytes in the chimeric calf might therefore be expected to supply acidic $\alpha$-mannosidase in sufficient quantities to induce at least partial mitigation of the disease.

The apparent reduction in vacuolation of Kupfer cells in the liver of the chimera was supported by a low level of storage-type material (as measured by hexosamine) relative to that found in the five mannosidosis control calves. The pathology and the low 
Table 1.

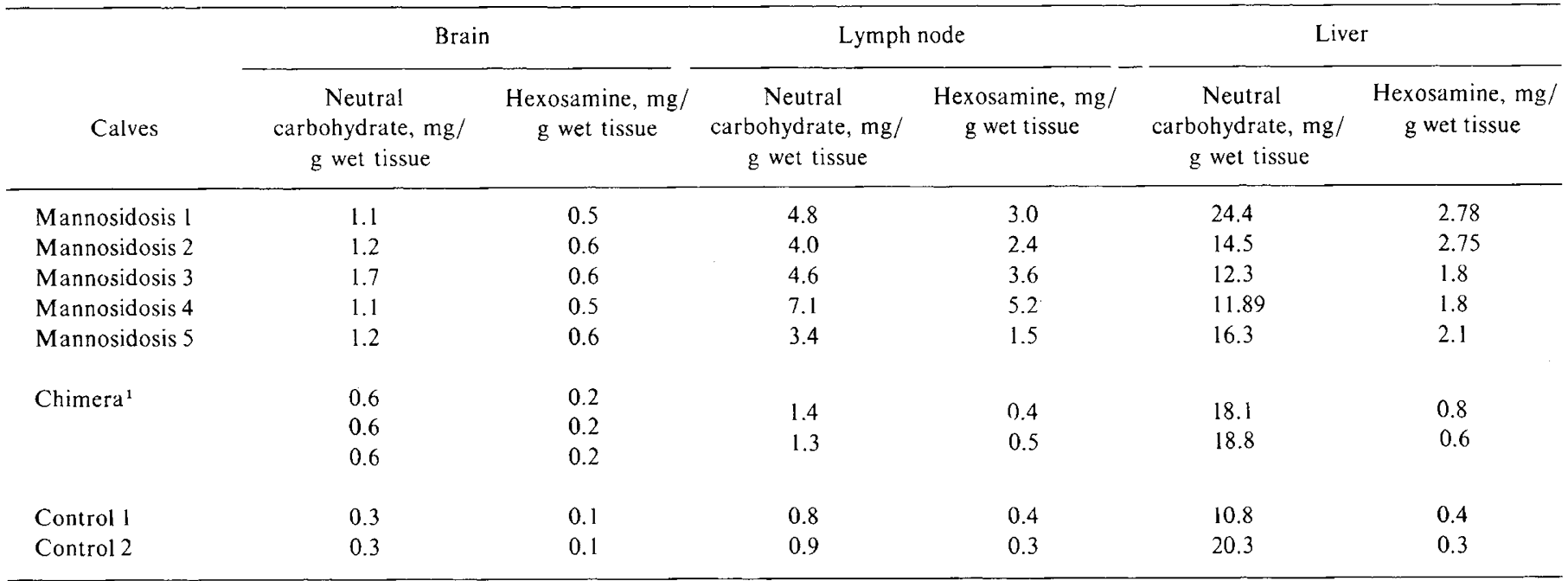

${ }^{1}$ All samples for chimeric calf are triplicate/duplicate.

$\alpha$-mannosidase activity in the central nervous system were similar to that of mannosidosis calves, implying a lack of effective therapy in this organ. However, the level of storage product was considerably less than in the five other calves with mannosidosis and only slightly greater than in the two normal controls. There is thus a strong implication on chemical grounds that some enzyme could have reached the central nervous system and catabolized stored oligosaccharides. The blood-brain barrier is considered a formidable obstacle in enzyme replacement therapy, so perhaps there is an alternative explanation. It is possible that there was some loss or excretion of storage oligosaccharides from cells of the central nervous system or other organs with consequent partial equilibration between body compartments and tissues. Their degradation, either extracellularly or in other organs containing the replaced enzyme, could create a negative concentration gradient and provoke an increased release of the storage material from tissues not directly affected by the replaced enzyme. The fact that storage oligosaccharides are excreted in the urine indicates at least some movement between tissues (16). Desnick (4) favors a similar hypothesis in regard to beneficial results after kidney transplants in patients with Fabry's disease. If such an hypothesis is valid, then the use of immobilized enzymes plus ancillary treatment aimed at removing storage material from cells might be a practical approach to therapy, at least in certain selected diseases. Further experiments to test this hypothesis are warranted, particularly with expendable animal models such as mannosidosis calves.

Using multiple treatments with concentrated leucocyte suspensions containing $70-90 \%$ of lymphocytes. Knudson et al. (14) obtained increased urinary excretion of glycosaminoglycans and some clinical improvement in a patient with type II mucopolysaccharidosis. In contrast, the lymphocyte transplant in the chimeric calf with mannosidosis occured during pregnancy, therefore some acidic $\alpha$-mannosidase would have been available from an early stage of fetal development. Failure to significantly prevent or alter the eventual clinical course of the disease even under these favorable transplant conditions is disappointing and indicative that tissue or organ transplants alone are unlikely to be a successful cure of diseases with severe neurologic manifestations. However, such a result was not unexpected. An encouraging aspect of this study was the observation that visceral lesions and the storage of oligosaccharides were greatly reduced in the chimera and if this disease had been purely visceral it is postulated that the transplant would have been reasonably effective. As such it shows promise that organ or tissue transplants may be effective in the few inborn errors of lysosomal catabolism without severe neurologic symptoms. So far only kidney transplants in Fabry's disease have produced encouraging results $(5,18)$.

\section{SUMMARY}

Enzyme replacement therapy was studied in a chimeric mannosidosis calf which had received a natural transplacental transplant of normal lymphocytes from its co-twin. There was considerable reduction in the pathology of certain organs and in the amount of storage oligosaccharides, but the clinical course of this neurologic disease was not significantly altered. It was postulated that if this disease had been purely visceral the transplant would have been relatively effective.

\section{REFERENCES AND NOTES}

1. Bach, G., Friedman, R., Weissman, B., and Neufeld, E.: The defect in the Hurler and Scheie syndromes: Deficiency of $\alpha$-L-iduronidase. Proc. Nat. Acad. Sci. U. S. A., 69: 2048 (1972)

2. Basrur, P. K., and Gilman, J. P. W.: Blood culture method for the study of bovine chromosomes. Nature, 204: 1335 (1964).

3. Boyum, A.: Separation of leucocytes from blood and bone marrow. Scand. J. Clin. Lab. Invest., 21: Suppl. 97 (1968).

4. Desnick, R. J.: Allotranslantation in genetic disease. In: J. M. Tager, G. J. M. Hooghwinkel, and W. T. Daems: Enzyme Therapy in Lysosomal Storage Diseases (North-Holland Publishing Co., Amsterdam-Oxford, 1974).

5. Desnick, R. J., Allen, K. Y., Simmons, R. L., Woods, J. E., Anderson, C. F. Najarian, J. S., and Krivit, W.: Fabry disease: Correction of the enzymatic deficiency by renal transplantation. In: D. Bergsma: Enzyme Therapy in Genetic Diseases: Original Article Series, Vol. IX (National FoundationMarch of Dimes, New York, 1973).

6. Di Ferrante, N., Nichols, B. L., Knudson, A. G., McCredie, K. B., Singh, J., and Donnelly, P. V.: Mucopolysaccharide storage diseases: Corrective activity in normal human serum and lymphocyte extracts. In: D. Bergsma: Enzyme Therapy in Genetic Diseases: Original Article Series, Vol. IX (National Foundation-March of Dimes, New York, 1973).

7. Dubois, M., Gillies, K., Hamilton, J. K., Rebers, P. A., and Smith, F.: Colorimetric method for determination of sugars and related substances. Anal. Chem., 28: 350 (1956).

8. Hocking, J. D., Jolly, R. D., and Batt, R. D.: Deficiency of $\alpha$-mannosidase in Angus cattle. Biochem. J., 128: 69 (1972).

9. Jolly, R. D.: The pathology of the central nervous system of pseudolipidosis of Angus cattle. J. Path., 103: 113 (1971).

10. Jolly, R. D.: Mannosidosis of Angus cattle-A prototype control program for some inherited diseases. In: C. A. Brandley and C. E. Cornelius: Advances in Veterinary Science and Comparative Medicine, Vol. 19 (Academic Press, New York, 1975).

11. Jolly, R. D., Digby, J. G., and Rammell, C. G.: A mass screening programme of Angus cattle for the mannosidosis genotype-A prototype programme for control of some inherited diseases in animals. N. Zealand Vet. J., 22: 218 (1974).

12. Jolly, R. D., Thompson, K. G., and Tse, C. A.: Evaluation of a screening programme for identification of mannosidosis heterozygotes in Angus cattle. N. Zealand Vet. J., 22: 185 (1974).

13. Jolly, R. D., Thompson, K. G., Tse, C. A. Munford, R. I., and Merrall, M. Identification of mannosidosis heterozygotes-Factors affecting normal plasma $\alpha$-mannosidase levels. N. Zealand Vet. J., 22: 155 (1974).

14. Knudson, A. G., Di Ferrante, N., and Curtis, J. E.: Effect of leukocyte transfusion in a child with Type 11 mucopolysaccharidosis. Proc. Nat. Acad Sci. U. S. A., 68: 1738 (1971). 
15. Neufeld, E. F., and Cantz, M. J.: Corrective factors for inborn errors of mucopolysaccharide metabolism. Ann. N. Y. Acad. Sci., 179: 580 (1971).

16. Nordén, N. E., Lundbald, A., Ökerman, P., and Jolly, R. D.: Mannosidosis in Angus cattle: Partial characterisation of two mannose containing oligosaccharides. Fed. Eur. Biochem. Soc. Lett., 35: 209 (1973).

17. O'Brien, J. S., Miller, A. L., Loverde, A. W., and Veath, M. L.: Sanfillipo disease type B: Enzyme replacement and metabolic correction in cultured fibroblasts. Science, 181: 753 (1973).

18. Philippart, M.: Fabry disease: Kidney transplantation as an enzyme replacement technique. In: D. Bergsma: Enzyme Therapy in Genetic Diseases Original Article Series, Vol. IX (National Foundation-March of Dimes, New York, 1973).

19. Phillips, N. C., Robinson, D., Winchester, B. G., and Jolly, R. D.: Mannosidosis in Angus cattle-The enzymic defect. Biochem. J., 137: 363 (1974).
20. Thompson, K. G., Jolly, R. D., and Rammell, C. G.: Lymphocyte $\alpha$ mannosidase-A supplementary test for determining mannosidosis genotype. N. Zealand Vet. J. (1976).

21. Whittem, J. H., and Walker, D.: Neuronopathy and pseudolipidosis of Aberdeen Angus calves. J. Path. Bacteriol. 74: 281 (1957).

22. Lymphoprep, Nygegaard \& Co., Oslo, Norway.

23. B. D. H. Chemicals, Ltd., Poole, England.

24. Fluka Durcupan, ACM, Switzerland

25. This investigation was supported by National Institutes of Health Research Grant No. RO1-NS 11238-02 from the Institute of Neurological Diseases and Stroke.

26. Requests for reprints should be addressed to: R. D. Jolly, Ph.D., Faculty of Veterinary Science, Massey University, Palmerston North, New Zealand.

27. Accepted for publication November 19, 1975.
Fetus liver

human growth hormone ornithine decarboxylase insulin

\section{Ornithine Decarboxylase Activity in Human Fetal Liver}

DANIEL R. WOLPAW AND ALAN L. SCHWARTZ ${ }^{(24)}$

Department of Pharmacology, School of Medicine, Case Western Reserve University, Cleveland, Ohio, USA

Extract

In human fetal liver ornithine decarboxylase (EC. 4.1.1.17 $(O D C)$ ) was found to have $a K_{m}$ of $3.3 \times 10^{-4}$ M. During human fetal development, hepatic ODC activity declined from a peak of 379 $\mathrm{pmol} / 60 \mathrm{~min} / \mathrm{mg}$ protein in the youngest tissue examined $(5.2 \mathrm{~cm}$ crown-rump length, 10 weeks of gestation) to values of $1.3 \pm 0.2$ in fetuses greater than $12 \mathrm{~cm}$ (14-15 weeks of gestation). Explants of human fetal liver maintained in organ culture for $32 \mathrm{hr}$ demonstrated no ODC activity in the presence or absence of insulin (1 $\mathrm{U} / \mathrm{ml}$ ). Explants of rat fetal liver achieved a steady state of ODC activity (12\% of the fresh tissue activity) after $16 \mathrm{hr}$ in organ culture and maintained this for an additional $14 \mathrm{hr}$.

\section{Speculation}

Regulation of hepatic ODC activity in the developing human fetus may result from hormonal influences, particularly human growth hormone (HGH) and very possibly human chorionic somatomamotropin (HCS).

Ornithine decarboxylase has recently emerged as a key enzyme in the synthesis and regulation of the polyamines, spermine and spermidine (9). This enzyme is responsible for shunting ornithine from the urea cycle to produce putrescine, a necessary intermediate in polyamine biosynthesis. Putrescine combines with a compound derived from L-methionine to form spermidine, which in turn yields spermine. ODC has been characterized in a variety of tissues, including fetal rat and fetal chick (16), and to a limited extent in human fetal brain and liver (17).

Attention has focused on ODC because of the increasingly important role assigned to polyamines in nucleic acid and protein synthesis, especially in association with rapidly proliferating tissues (e.g., fetal, neoplastic, regenerating, etc.) (9). Furthermore, this enzyme is extremely sensitive to hormonal stimulation. Growth hormone produces a marked increase in activity $(1,16)$, and Mallette and Exton (5) have reported stimulation of ODC activity in perfused rat liver by both insulin and glucagon. Considering the important metabolic regulatory roles of insulin and glucagon in human fetal liver (13-15), we initiated this study to expand the data available on ODC in human fetal liver and to explore its relationship to these hormones.

This study involved characterization of ODC in developing human fetal liver.

\section{MATERIALS}

$\left[{ }^{14} \mathrm{C}\right]$ Carboxylornithine (specific radioactivity $61 \mathrm{mCi} / \mathrm{mmol}$ ) was obtained from Amersham-Searle, Des Plaines, Ill. The organ culture medium was a modified Eagle's minimal essential medium in Hank's balanced salt solution and was obtained from Grand Island Biologicals, N.Y. (12). All other chemicals were purchased from Sigma Chemical Co., St. Louis, Mo.

Human fetal liver tissue was obtained at legal therapeutic abortion by hysterotomy (19). These tissues were either quickfrozen immediately in liquid nitrogen and stored up to 1 year at $-70^{\circ}$ until assayed or were incubated in organ culture and then quick-frozen and stored at $-70^{\circ}$. Gestational ages were determined from the nomogram of Tanimura et al. (18).

All rats used were Holtzman strain Sprague-Dawley. Regenerating liver tissue was obtained $10-14 \mathrm{hr}$ after partial hepatectomy and assayed immediately or quick-frozen and stored as above. Fetal liver tissue for organ culture and developmental data were obtained from rats mated for $16 \mathrm{hr}$. The dam was killed by a blow to the head and the entire uterus was removed rapidly. The tissue 